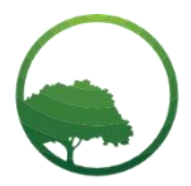

Research in Business \& Social Science

IJRBS VOL 11 NO 1 (2022) ISSN: 2147-4478

\title{
Model of legal protection for aircraft property guarantee in Indonesia
}

\author{
(D) Putri Purbasari Raharningtyas Marditia ${ }^{(a) *}$ (D) Hans Sebastian Adiwinata ${ }^{(b)}$ \\ ${ }^{(a, b)}$ Faculty of Law, Atma Jaya Catholic University, Jakarta, Indonesia
}

Crossref

A R T I C L E I N F O
Article history:
Received 16 December 2021
Received in rev. form 02 Feb. 2022
Accepted 10 February 2022
Keywords:
Regulatory Model, Legal Protection,
Aircraft, Material Guarantee
JEL Classification:
K10

\begin{abstract}
A B S T R A C T
Airplanes are legal objects of high economic value (high valuable assets) so that airplanes can be used as assets to guarantee the risk of debt agreements. The regulatory provisions related to guarantees for aircraft are based on the provisions of Law Number 15 of 1992 concerning Aviation which stipulates that aircraft can be used as collateral through a mortgage guarantee institution, but in its development the regulation was replaced by Law Number 1 of 2009 concerning Aviation, which in its latest arrangement eliminates the ability of aircraft to be subject to collateral. This condition creates a legal vacuum because it does not provide alternative settlements and adjustments to aircraft that have been and will become objects of guarantee. So based on these conditions, it is necessary to have a regulatory model that can be used as a reference in the formulation of regulations related to the continuation of aircraft as an object of guarantee. The regulatory model referred to in this paper is in the form of formulating a regulatory pattern that provides a comprehensive overview of the Guarantee Institution, Implementation Mechanism, Guarantee Execution Mechanism and Guarantee Implementation Authority that adapts to the regulatory system in Indonesia. To describe the regulatory model, the research method used is a normative juridical method based on a statutory and conceptual approach. With the aim of being able to comprehensively present a form of continuous pattern of arrangements that will form a protection system for creditors by focusing on the Guarantee Institution, the guarantee implementation mechanism, the guarantee execution mechanism and the Guarantee Implementing Authority for aircraft.
\end{abstract}

(C) 2022 by the authors. Licensee SSBFNET, Istanbul, Turkey. This article is an open access article distributed under the terms and conditions of the Creative Commons Attribution (CC BY) license (http://creativecommons.org/licenses/by/4.0/).

\section{Introduction}

Based on the consideration of Law No. 1 of 2009 concerning Aviation (hereinafter Law No. 1 of 2009) it is explicitly stated that the aviation industry is a capital-intensive industry. Therefore, specifically towards the legal isssues regarding aircraft financing have a high risk which frequently caused the subordinate position of the creditor (Yahanan, 2020; Wirsamulia, 2021), due to the aircraft is a high value movable asset which able to travel rapidly from one jurisdiction into another jurisdiction within a short time (Shadrina, 2011; Yeomans, 1986). According to the international perspective, there are several recognitions to set an aircraft as a collateral such as the whole aircraft including the spareparts, the separation of the spareparts from the aircraft, an aircraft currently in the construction stage, all aircraft (airlines' fleets) legally owned by an airline, and all the property owned by an airline (Yahanan, 2020). A collateral can be defined as a several regulations to implement a legal protection for the creditor (Hartanto, 2015).

Essentially, according to Law No. 15 of 1992 regarding Aviation as the lex priori, it is explicitly stated that a registered aircraft can be set as a collateral by using the mortgage (hipotek) in Indonesia, but it also stated that the procedurals in order to set a registered aircraft by using mortgage will be further regulated by the Government Regulation (PP), but nowadays as the lex priori is revoked through Law No. 1 of 2009, there is no regulation ruling the procedurals to set the aircraft as collateral by mortgage. Therefore, based on common practices in Indonesia, an aircraft can be set as a collateral by separating its part (airframes, engines) and not a whole

\footnotetext{
* Corresponding author.

(C) 2022 by the authors. Hosting by SSBFNET. Peer review under responsibility of Center for Strategic Studies in Business and Finance.

https://doi.org/10.20525/ijrbs.v11i1.1602
} 
aircraft by using fiduciary transfer of ownership. The legal issues existing in Indonesia is the occurrence of legal vacuum for setting an aircraft as collateral which implied to the creditor position as the chargee (Hartanto, 2015; Cogliati-Bantz, 2010).

It can be identified through the lex priori specifically according to Article 12 (1) Law No. 15 of 1992 which explicitly state that a whole aircraft can be set as collateral by mortgage (hipotek), furthermore according to Article 12 (3) Law No. 15 of 1992 stated that the procedurals to set an aircraft as collateral will be stipulated under the Government Regulation, however up to today, the Government Regulation has not yet been promulgated. Furthermore, the provision of Law No. 1 of 2009 not explicitly or implicitly stated the guarantee to set an aircraft as collateral.

Therefore, in Indonesia, the aircraft can be set as a mortgage by partially as according to the Law No. 42 of 1999 regarding Fiduciary Transfer of Ownership, there is no provisions that prohibit the debtor to set an aircraft partially as a collateral. The implementation of the fiduciary transfer of ownership reduces the legal certainty, which is urgently needed in its implementation, therefore based on the necessity to set an aircraft as a collateral, we are extremely motivated to conduct this research regarding the Model Regultion of Aircraft Property Guarante in Indonesia.

In this study, normative legal research method has been used through Model of Legal Protection for Aircraft Property Guarantee in Indonesia. The research was conducted with a library-based approach that focuses on reading and examining primary and secondary legal sources. Primary legal sources are actual sources of law, namely, laws and court decisions and regulations related to Model of Legal Protection for Aircraft Property Guarantee in Indonesia. Meanwhile, secondary legal sources are materials that include commentary on the law discovered in legal literatures and journals. The approach used by the author for this legal writing in this study is a statutory approach (the statute approach). This study continues with a literature review and finalizes with key contributions.

\section{Literature Review}

The author's team reviewed the four material guarantee institutions that received recognition under the positive legal regime of Indonesia, so it can be stated that fiduciary guarantees are material guarantee institutions that are considered the most adequate in charging aircraft as material guarantees. However, it turns out that Indonesia has a weakness, namely that there are no legal rules that comprehensively provide arrangements for the loading of aircraft as a whole (whole aircraft) as material guarantees. In the context of tabulating several previous studies that conducted an assessment of the effort to load aircraft as objects of material security in Indonesia, it can be stated as follows:

Andhanaricwari et al. (2021) presented juridical analysis of aircraft guarantee practices in terms of the Indonesian guarantee law. They explained airplanes that already have registration marks and Indonesian nationality cannot be charged as material security by using a mortgage institution. The business actors in principle deal with the legal vacuum by imposing the components of the aircraft that make up an aircraft unit using a fiduciary guarantee institution. They found that for the Government of Indonesia in realizing legal certainty and protection to creditors through the establishment of laws and regulations related to the most appropriate material guarantee institution in charging aircraft as objects of material security.

Badriyah, S. M. (2014) studied of the aircraft problems as collateral on credit agreements in aviation industry development. They have explained the legal regime of material security in Indonesia, there is legal ambiguity in charging aircraft as material security. This ambiguity results in a subordinate position for creditors as recipients of material guarantees. They found that for the Government of Indonesia to immediately establish appropriate laws and regulations regarding the loading of aircraft as material security. The Parties should pay attention to the principles attached to aircraft as sui generis in determining the appropriate material security institution.

\section{The Landscape of Regulations in Indonesia}

In Indonesia's collateral law regime, there are several institutions managing the collateral law, that are regulated either by The Indonesian Civil Code / Kitab Undang-Undang Hukum Perdata (hereinafter KUHPerdata) or by other regulations apart of KUHPer. First of all, the pledge guarantee institution, regulated by KUHPerdata. In this case, according to Article 1150 of KUHPerdata, the imposement of pledge can only be exercised to tangible object and intangible object. In Article 1152 of KUHPerdata, it is explicitly stated that the existence of objects which pledge right is imposed to, must be under authorization of the receiver of said right. If the object which already being imposed of pledge right is not under the possession receiver of the pledge right, said right will be invalid (Yunari, 2021). The imposition of pledge right to an aircraft is incorrect. In this case, the aircraft is an object which bolsters debtor's operational activity and does not fulfill the principle of inbezistelling, that require the existence of said aircraft to be under creditor's authorization as the receiver of the pawn right.

Second, the hypothec guarantee institution is regulated by KUHPerdata. According to Article 1162 in conjunction with Article 1167 KUHPerdata, hypothec can only be granted to immovable objects. Even though the provision of lex priori within Regulation 15/1992, as mentioned before by the writer team, recognized the existence of the imposition of hypothec to aircrafts until the publication of Regulation 1/2009, the publication of the mentioned government regulation within Article 12 section 3 of Regulation 15/2009 never arrived at fruition. The nonexistent of Indonesia's regulation for the imposition of hypothec on aircrafts have risen the inability of 
authorized agency to register aircraft's hypothec right. The registration of hypothec rights performed by the Directorate General of Civil Aviation, may only issue a Letter of Explanation and instead of Grosse Hypothec Deed (Wirsamulia, 2021).

Third, the fiduciary guarantee institution is regulated by Regulation No. 42 Year 1999 concerning Fiduciary Guarantee (hereinafter Regulation 42/1999). According to Article 1 number 1 of Regulation 42/1999, fiduciary guarantee has the principle of belief as its fundamental. In this matter, there is the existence of transfer of ownership right of objects from debtor to creditor while the existence of the whereabout of said object is remained under the debtor's authority. According to Article 3 of Regulation 42/1999, there are exceptions within the fiduciary guarantee institution against mortgage right relating to lands and buildings, provided the current regulations stipulate that the object of fiduciary right should be registered, hypothec of registered boats of $20 \mathrm{~m}^{3}$ or more, hypothec of aircrafts, and pledge rights. If Article 3 of Regulation 42/1999 is interpreted legally, it is legal to impose properties guarantee on the components of an aircraft. The legal practices in Indonesia concerning the legal vacuum of imposing property guarantee on aircrafts, resulted in the fiduciary guarantee is considered as the most suitable right and can accommodate the property guarantee of aircrafts. In this case, the components that make the whole aircraft, which can be used as a property guarantee, are classified as airframe and body of aircraft, that consists of wings, nose cone, cabin, empennage, and the engine of the aircraft (Wirsamulia, 2021).

Fourth, mortgage right is regulated by Regulation No. 4 Year 1996 concerning Mortgage right of land and the properties associated with the land (hereinafter Regulation 4/1996). Fundamentally, the definition of mortgage right within Article 1 number 1 of Regulation 4/1996 interpreted as the mortgage right can be imposed to immovable objects, which are the lands and the properties associated with said land. For this matter, it can be concluded that the existence of mortgage right is possible to be imposed to the right of lands and the properties associated with said lands.If it is linked to international collateral asset, aircraft, be it the frame of the aircraft and/or the engine of the aircraft, all of them cannot be imposed with property guarantee using mortgage right as the legal basis.

\section{Best Practice: The Implementation of Aircraft Property Guarantee in Germany}

One of many countries that can be portrayed as a role model in order to arrange the framework of model law concerning the imposition of aircraft as collateral, is Germany. Germany has recognized the regulation providing the necessary legal basis to aircraft property guarantee, which is Luftfahrzeug-Registerpfandrecht, specifically with Gesetz über Rechte an Luftfahrzeugen (hereinafter German Act on Rights in Aircraft) (Mann, 2009). There are similarities in principles, between Indonesia and Germany, about the imposition of aircraft as collateral, provided said aircraft bears the mark of registration from the Germany Federal Aviation Office (Luftfahrt Bundesamt), and the mark of nationality (Mann, 2009), followed by the listing of aircraft in Register fur Pfandrechte an Luftfahrzeugen. Aircrafts allowed to be registered are: aircrafts that are not registered to foreign countries and wholly owned by the legal subject of Germany, Switzerland, or legal subject that comply to European Union (Bisset, 2017). The aircraft registration must be using a Notarial Deed and registered to Aircraft Hypothec Registry in the local courts of Braunschweig.

According to Article 9 of German Act on Rights in Aircraft, Germany will only recognize the imposition of whole aircraft as collateral through mortage institution. Aside from the recognition of property guarantee for imposing aircraft as collateral in Germany, there are also 2 guarantee institutions known as rentetion of title and chattel mortgage. The airframe and the engine of the aircraft can be used as collateral using retention of life, according to Article 449 of Germany Civil Codes (Bürgerliches Gesetzbuch) or chattel mortgage, according to Article 929 and 930 Germany Civil Codes.

The practices of imposing property guarantee on an aircraft as collateral in Germany, at the very least, are supported by 3 guarantee institutions. First is mortgage, where the whole aircraft can be used as a collateral after being registered with hypothec deed and listed in the Aircraft Mortgage Register under the local court of Braunwisch. Second and third are respectively chattel mortgage and retention of life. In this case, the collateral assets are the components making the whole aircraft, such as airframes and/or the engine of said aircraft. However, those components must not be equipped on said aircraft.

During the imposition of a whole aircraft as a collateral through mortgage institution, according to Article 80 of Germany Act on Right in Aircraft, there are a number of requirements must be fulfilled such as: the aircraft registration page, the serial manufacture number of the aircraft and the registration mark, model specification of the aircraft, identities of the creditors with the total loan, identity of the debtor as the owner of said aircraft, the proof of ownership in form of notarial deed, and the registration cost for the aircraft property guarantee (Brown and Mannsfeldt, 1987). In accordance to Article 86 section 1 of German Act on Rights in Aircraft in conjunction with Article 37 section 1 of Ship Register Regulation, stated that the requirement of proof of ownership for the aircraft must be in a form of a notarial deed. After all those requirements are completed, the application of registry for the aircraft as a collateral shall be executed through German Aircraft Mortgage Register managed by the local court of Braunschweig (Brown and Mannsfeldt, 1987).

The existence and effectivity of the mortgage implementation to aircraft shall only be applied to third parties, after the registration of the aircraft is listed in the German Aircraft Mortgage Register. After the registry and the listing are completed, the German Aircraft Mortgage Register will release a document as the proof of registry (extract of the German Aircraft Register Mortgage showing the registration of the mortgage). According to Article 25 section 1 of German Act on Rights in Aircraft, aircraft that has been registered as collateral, is given the right to be preceded before other rights that will be registered in the near future. 
Principally, in the event of a breach of contract by the debtor, creditor cannot arbitrarily execute the aircraft that was imposed as collateral. According to Article 171a of Compulsory Auction of Immovable Property Act (Zwangsversteigerungsgesetz or ZVG) (hereinafter Compulsory Auction of Immovable Property Act), creditors are obliged to submit an application to the local court of Braunschweig, by proving the legal fundamental of the debtor's ownership right of said aircraft (Keaveny and Murray, 2013). According to Article 19 of Compulsory Auction of Immovable Property Act, the local court of Braunschweig will release a confirmation for compulsory auction, that caused the debtor to be unable to sell the aircraft that has already been imposed as collateral. According to Article 171 (c) (2) of Compulsory Auction of Immovable Property Act, after the release of the confirmation of compulsory auction, the aircraft will be under custody for it to be auctioned off.

The tabulation of the comparison between the current law of Indonesia against Germany's laws having the regulation for the imposition of collateral for an aircraft, as follows:

Table 1: Comparison of Landscape of Regulations in Indonesia in Indonesia and Germany

\begin{tabular}{|c|c|c|}
\hline $\begin{array}{l}\text { Variable of Similarity and } \\
\text { Difference }\end{array}$ & Indonesia & Germany \\
\hline Aircraft Registry & $\begin{array}{l}\text { According to Article } 24 \text { of Regulation } 1 / 2009 \text {, } \\
\text { Aircraft must be in operation within Indonesia for } \\
\text { it to be registered and to receive the mark of } \\
\text { registry and nationality. }\end{array}$ & $\begin{array}{l}\text { According to Article } 14 \text { of Luftverkhers- } \\
\text { Zulassungs-Ordnung "German Regulation } \\
\text { on Air Traffic Permission", every aircraft } \\
\text { must be in operation within the jurisdiction of } \\
\text { Germany to be registered. In this matter, } \\
\text { registration will be done by Germany Federal } \\
\text { Aviation Office (Luftfahrt-Bundesamt). }\end{array}$ \\
\hline Hypothec of Aircraft & $\begin{array}{l}\text { In the current Indonesia law regime, Indonesia } \\
\text { doesn't recognize the imposition of whole } \\
\text { aircraft using hypothec guarantee. There are no } \\
\text { institution in Indonesia having the authority to } \\
\text { register the aircraft as a hypothec guarantee and } \\
\text { to release Grosse Hypothec Deed. }\end{array}$ & $\begin{array}{l}\text { Imposition of whole aircraft, as regulated in } \\
\text { German Act on Rights in Aircraft, is possible. } \\
\text { Registry of hypothec on the whole aircraft } \\
\text { can be done with notarial deed and with the } \\
\text { registration of local court in Braunschweig. }\end{array}$ \\
\hline $\begin{array}{l}\text { Fiduciary Guarantee for } \\
\text { Aircraft }\end{array}$ & $\begin{array}{l}\text { Can be used as a safety measure against any } \\
\text { dysfunction on hypothec institution. In this case, } \\
\text { imposition will be done on the airframe of the } \\
\text { aircraft and/or the engine of the aircraft, as they } \\
\text { are components of aircraft and currently, there is } \\
\text { no prohibition within Regulation } 42 / 1999 \text { about } \\
\text { imposing fiduciary guarantee upon components } \\
\text { of a whole aircraft. }\end{array}$ & $\begin{array}{l}\text { Better known as the Retention of Title and } \\
\text { Chattel Mortgage, they are regulated within } \\
\text { Germany Civil Codes. } \\
\text { Provided it is agreed by both parties and the } \\
\text { engine and/or airframe of the aircraft is not } \\
\text { currently in used on an aircraft and those } \\
\text { items are within certain jurisdictions, then } \\
\text { Retention of Title and Chattel Mortgage can } \\
\text { be imposed to the engine and/or airframe. }\end{array}$ \\
\hline $\begin{array}{l}\text { Executorial Capability of } \\
\text { Aircraft as Collateral }\end{array}$ & $\begin{array}{l}\text { In the event that the component of an aircraft is } \\
\text { imposed with fiduciary guarantee, then according } \\
\text { to Regulation } 42 / 1999 \text { and The Decision of } \\
\text { Constitutional Court No. } 18 \text { of } 2019 \text {, executorial } \\
\text { capability can be used, provided that there is an } \\
\text { agreement between debtor and creditor, also the } \\
\text { creditor have to submit an executorial application } \\
\text { to the District Court. }\end{array}$ & $\begin{array}{l}\text { In the event that an aircraft is imposed with } \\
\text { mortgage, according to Article 171a of } \\
\text { Compulsory Auction of Immovable Property } \\
\text { Act, creditor can execute said aircraft through } \\
\text { an compulsory auction, after submitting the } \\
\text { application to the local court of } \\
\text { Braunschweig, that will release a } \\
\text { confirmation of compulsory auction. }\end{array}$ \\
\hline
\end{tabular}

\section{An Analysis on the Needs of Regulations and Recommendation of Regulations Concerning the Creation of a Model law}

According to the review on Indonesia's regulation landscape concerning guarantee institution that capable to be imposed to an aircraft, it is known that the needs of regulations are focused into 2 factor: (1) the needs of regulations concerning imposition of aircraft as collateral; (2) Regulations that keep an eye on the charateristics of properties on aircrafts as sui generis, in order to determine the most suitable guarantee institution (Keaveny and Murray, 2013). The recent problems that Indonesia has faced in order to create a model law are: (1) the regulations for aircraft hypothec institution; (2) the common practices of using fiduciary institution on aircraft as an alternative in response of the current legal vacuum; (3) the provisions and mechanisms of aircraft executorial as collateral.

Using the needs and problems that has risen during the creation of said regulations, writer has attempted research about the comparison of the implementation of best practices in other countries, such as Germany, to obtain a comprehensive image regarding 
the regulations concerning guarantee institution able to be imposed on aircrafts in Indonesia. The result of this research, may act as a foundation to determine and to analyze the needs of regulations in Indonesia, as explained below:

\section{The Legal Status of Aircraft Collateral Law Within the Development of Collateral Assets in Indonesia}

Principally, hypothec institution which is regulated as lex priori by Regulation 15/1992, stated that hypothec institution can be applied to impose aircraft as collateral. Unfortunately, up to today there is no government regulation that explicitly stipulate such. In such a way that common practices of using fiduciary guarantee on aircraft, in form of said aircraft's components is applied instead (Keaveny and Murray, 2013)

\section{The Framework of Hypothec Regulations on Aircraft}

In Indonesia, the current law regime does not acknowledge the imposition of whole aircraft by using hypothec guarantee. No institutions in Indonesia authorized to perform a hypothec registration on aircraft and to issue Grosse Hypothec Deed. Meanwhile, in Germany, regulations of hypothec guarantee may be imposed on whole aircraft, according to German Act on Rights in Aircraft. Hypothec registration of whole aircraft shall be done with notarial deed and the registration on the local court of Braunschweig.

\section{The Review of The Implementation of Fiduciary Guarantee on Aircraft}

Indonesia's fiduciary guarantee is used as a safety measure against any disfunctions of hypothec guarantee institution. In this case, hypothec is imposed on the airframe and/or the engine of an aircraft, provided that there is no prohibition within Regulation 42/1999 about imposition to components of a whole aircraft. The practices of imposing guarantee on aircraft are known as Retention of Title and Chattel Mortgage, according to Germany Civil Codes. Provided that it is agreed by both parties and the engine and/or the airframe of an aircraft is not currently equipped, Rentention of Title and Chattel Mortgage is allowed to be imposed to said engine and/or airframe.

\section{The Executorial of Aircraft as Collateral}

The mechanism of executorial on an aircraft property guarantee in Indonesia is properly regulated, therefore if the components of the aircraft are imposed with fiduciary guarantee, according to Regulation 42/1999 and The Decision of Constitutional Court No. 18 of 2019, executorial may be implemented, provided that there is an agreement between debtor and creditor, also the creditor have to submit an application of executorial to the District Court.

Meanwhile, the common practices in Germany regulates that if the whole aircraft is imposed with mortgage, according to Article 171a Compulsory Auction of Immovable Property Act, the creditor can execute said aircraft through a compulsory auction, provided the creditor submit an application to the local court of Braunschweig, that will release a confirmation of compulsory auction.

The needs of regulations concerning imposition of guarantee on aircraft with the necessary facilities that can provide a fast and easy process during the implementation, liquidation, and realization of said guarantee, are a need and a requirement, in respect of the ratification of Cape Town Convention of 2001 that set an obligation for Indonesia, to facilitate the utilization of aircrafts as a transportation or as an object to be imposed as collateral. So it is important to create a separate rules about the regulations for guarantee institution on aircraft, with the intention of creating a utility of said guarantee.

\section{Recommendation for Regulation: Theories and The Approach on The Creation of Model law}

The approach that was used, is the concept of economic analysis of law, with utilitarianism as the primary foundation. The utilitarianism trend was introduced by Jeremy Bentham, who evaluated that good or bad deeds, moral or immoral, is not based on the utility it brings. .In this case, a good regulation, according to the concept of economic analysis of law, is if that regulation gives utility to many parties, where through the law, humans as economic entity, are given the choice to determine the most successful business and give them the assurance of enjoying their businesses (Bohlander, 2008). In this case, according to this approach, law has 2 roles that are : (1) Law as a means to attain individual happiness by becoming the control of individual interests, to assure the continuity of shared interests; (2) as a means to attain individual happiness by becoming a detterent of crime, as the nonexistence of crime will cause happiness .The realization of "Good Regulation", according to the concept of economic analysis of law, is a regulation that give utility to many parties and give protection insurance, using the fundamental that many parties benefitted from said regulation.

The approach of the concept of economic analysis of law, if applied in the development of the model law, then it will be based on the penta helix approach (Forss et al., 2021). This approach involves 5 main components for the creation of regulations and can be applied in the creation of economic digital regulation, that are: (1) the most affected group; (2) the main stakeholders; (3) interest groups; (4) advocacy groups; and (5) public at large. Its implementation, those 5 components will involve public sector, private sector, non-governmental organization, civilians, and academics (See Figure 1). 


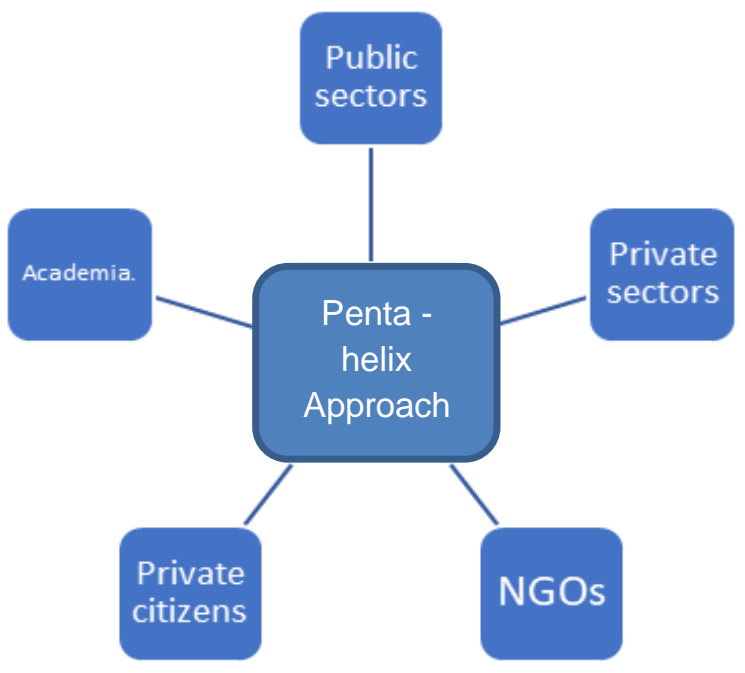

Figure 1: Penta Helix Approach in the Creation of Regulation

Several benefits for using this approach are:

i. Accumulation of power, capacity, and resources from stakeholders to create regulations that can accurately deal with the need of parties and can be functional;

ii. Involves the commitment of the stakeholders from the very start, so that the creation of regulations are a must-to-do;

iii. Easier implementation of regulations as the result of said commitment; and

iv. A throughout input from stakeholders for a comprehensive review that will be useful during the creation of regulations.

This approach is more feasible than the traditional approach of top down, for the purpose of the creation of regulations.

\section{Recommendation for Model law}

Recommendation for Model law that can be offered is to focus on the centralized development of those regulations with some points in mind, such as:

\section{Aircraft as Collateral}

\section{Aircraft and its components as collateral}

i. The regulation for Aircrafts as a movable object with special charateristics (sui generis). Naturally, Aircraft is classified as movable object, however within the national law, it is considered as a special case (sui generis), that aircraft is a movable object with special charateristic (sui generis). For a more detailed look, the legal status of aircrafts as movable objects, is legalized after the Dutch Parliament established the regulation that ratified the Geneva Convention of 1948, named The Convention on The International Recognition of Rights in Aircraft, that was signed in $29^{\text {th }}$ of June 1948. The result of such ratification, affected Dutch's aircrafts that those aircrafts can be imposed with chattle mortgage but cannot be imposed with pawn right.

ii. Aircraft and its components have been recognized internationally as collateral. Aircraft and its components that are commonly used as collateral are as follows (Juwana, 2001):

a. Aircraft with all its equipments and spare parts; (b) Spare parts that are not currently in used on an aircraft; (c) Aircrafts that are still in construction; (d) an armada of aircrafts that are owned by a company (fleet mortgage); (e) Entire assets of the aviation company, including the aircrafts and other apparatus (floating mortgage).

b. Registration as the legal basis of collateral

Aircrafts must be registered. Registration of said aircrafts performed by The Department of Civil Aviation, in form of The Ministry of Transportation. Registrations of aircrafts are done publicly and only valid on aircrafts that meet the following requirements: (a) bears the nationality of Indonesia; (b) is not registered in Indonesia or other countries; (c) has the maximum weight as regulated by KUHPerdata. 
Registration and nationality of aircrafts use "one registration" principle. Not a single aircraft that is officially acknowledged, has dual registration, hence the aircraft can be re-registered if the former registration has been removed and can be transferred to other countries. The prochedure of transferring the registration from 1 country to the other is regulated by their own respective regulations. Registration consisted of 3 types: (1) Registration for the Identity of Aircrafts as mode of transportation; (2) Registration for The Nationality of Aircrafts; (3) Registration of Aircraft Guarantee Deed.

\section{The applied Regulations for Guarantee Institution}

Guarantee institutions that can be imposed on aircrafts are fiduciary and hypothec. Why only 2 institutions? Due to the special charateristic of aircrafts (sui generis), hence for all of its components will be imposed by different guarantee institution. Hypothec Guarantee is required to impose a guarantee on whole aircraft while fiduciary guarantee is for spare parts.

\section{The mechanism of imposing guarantee on Aircrafts}

\section{Provisions for Deed of Guarantee and the Registration of Guarantee Agreements}

Provisions of deed of guarantee required that the registration has to be made in a form of notarial deed and registered. Provisions for the obligation to register hypothec agreements are stipulated in Article 1179 KUHPerdata, as those agreements must be registered in "Registration Book of Hypothec for Aircrafts" provided by Then Directorate General of Civil Aviation, that is appointed by the Minister.

\section{Institution For Guarantee Registration}

Its purpose is to store, maintain, and to remove the registration on aircrafts hypothec agreements. The completion of said registration requires information on the date of registration, the latest detailed address of its creditor and debtor, period of the repayment of loan, and loan requirements. Registration will be listed in the "Registration Book of Hypothec for Aircrafts".

\section{Mechanisms for The Execution of Aircraft as a Property Guarantee}

The mechanism for the execution of property guarantee on aircrafts must be according to the nationality wherein the aircraft were registered and the execution is implemented by the guarantee agreement where the applicable law for said agreement was agreed upon. The result of such execution is the erasure of the former registration of nationality and the aircraft will be registered to a new nationality only if the nature of said registration is cross border.

\section{Conclusions}

The needs of regulations concerning imposition of guarantee on aircraft with the necessary facilities which able to provide a fast and easy process during its implementation, liquidation, and realization are necessary and required, in respect to the ratification of Cape Town Convention of 2001 setting an obligation for Indonesia, to facilitate the utilization of aircrafts as a transportation or as an object to be imposed as collateral. In this matter, recommendation for Model law that can be offered is to focus on: (a) Aircraft and its components as collateral; (b) The mechanism for the imposition of property guarantee on aircrafts; (c) The mechanism for the execution of guarantee on aircrafts.

Author Contributions: Conceptualization, PM., HA.; Methodology, PM., HA.; Data Collection, PM., HA.; Formal Analysis, PM., HA.; WritingOriginal Draft Preparation, PM., HA.; Writing—Review And Editing, PM., HA.; All authors have read and agreed to the published the final version of the manuscript.

Institutional Review Board Statement: Ethical review and approval were waived for this study, due to that the research does not deal with vulnerable groups or sensitive issues.

Data Availability Statement: The data presented in this study are available on request from the corresponding author. The data are not publicly available due to privacy.

Conflicts of Interest: The authors declare no conflict of interest.

\section{References}

Andhanaricwari, D. P., Abubakar, L., \& Handayani, T. (2021). Analisis Yuridis Terhadap Praktik Jaminan Pesawat Udara Ditinjau Dari Hukum Jaminan Indonesia. De Lega Lata: Jurnal Ilmu Hukum, 6(1), 65-79.

Badriyah, S. M. (2014). Problematika Pesawat Udara Sebagai Jaminan Pada Perjanjian Kredit Dalam Pengembangan Industri Penerbangan. Masalah-Masalah Hukum, 43(4), 546-552.

Bisset, M. (2017). Aviation Finance \& Leasing. London: Clyde \& Co LLP, Law Business Research.

Bohlander, M. (2008). Principles of German criminal law. Portland: Bloomsbury Publishing.

Brown, J. T., \& Mannsfeldt, U. (1987). Security Interests in Aircraft and Spare Parts V: Germany. Int'l Bus. Law., 15, 224.

Cogliati-Bantz, V. (2010). Disentangling the" Genuine Link": Enquiries in Sea, Air and Space Law. Nordic Journal of International Law, 79(3), 383-432. 
Forss, K. S., Kottorp, A., \& Rämgård, M. (2021). Collaborating in a penta-helix structure within a community based participatory research programme: 'Wrestling with hierarchies and getting caught in isolated downpipes'. Archives of Public Health, 79(1), $1-13$.

Hartanto, J. A. (2015). The Legal Development of Guarantee in Indonesia. JL Pol'y \& Globalization, 36, 57-61.

Juwana, H. (2001). Teaching International Law in Indonesia. Sing. J. Int'l \& Comp. L., 5, 412.

Keaveny, C., \& Murray, S. (2013). Aviation finance and leasing. Offshore Investment, 239, 12-14.

Mann, E. D. (2009). Aviation finance: An overview. The Journal of Structured Finance, 15(1), 109-117.

Shadrina, S. I. (2011). Cape Town Convention on International Interests in Mobile Equipment. Indonesian Journal of International Law, 8(3), 596-612.

Wirsamulia, F. (2021). The Legal Problem of Aircraft Mortgage in Indonesia. Journal of Legal, Ethical and Regulatory Issues, 24, $1-10$.

Yahanan, A. (2019). Aircraft Mortgage in Indonesia: Alternative Object of Material Guarantee as a Debt Settlement. https://www. ijrte. org/wp-content/uploads/papers/v8i2S9/B11260982S919. pdf, 8(2S9), 601-607.

Yahanan, A. (2020). Urgency of Regulation: Arrcraft as Object of Credit Guarantee. Diponegoro Law Review, 5(1), 19-33.

Yeomans, B. (1986). Recognition of States and Diplomatic Relations, Law of the Sea, Air and Space Law: Some Recent Developments. International \& Comparative Law Quarterly, 35(4), 975-990.

Yunari, S. B. (2021). The procedure of execution on foreign arbitral awards in Indonesia and issues. In Empowering Civil Society in the Industrial Revolution 4.0 (pp. 17-22). Routledge.

Publisher's Note: SSBFNET stays neutral with regard to jurisdictional claims in published maps and institutional affiliations.

\section{(a) (1)}

(C) 2022 by the authors. Licensee SSBFNET, Istanbul, Turkey. This article is an open access article distributed under the terms and conditions of the Creative Commons Attribution (CC BY) license (http://creativecommons.org/licenses/by/4.0/).

International Journal of Research in Business and Social Science (2147-4478) by SSBFNET is licensed under a Creative Commons Attribution 4.0 International License. 